\title{
CACAO SEED (THEOBROMA CACAO L.) EXTRACT GEL EFFECT ON THE NEUTROFIL NUMBER AFTER TOOTH EXTRACTION
}

Atik Kurniawati*, Dwi Riski Saputra**, Zainul Cholid $^{* *}$, Hendito K. Putra ${ }^{\star \star *}$

* Bagian Biologi Oral, Fakultas Kedokteran Gigi Universitas Jember

**Bagian Bedah Mulut, Fakultas Kedokteran Gigi Universitas Jember

***Mahasiswa Fakultas Kedokteran Gigi Universitas Jember

Correspondence : Atik Kurniawati, Bagian Biologi Oral, Fakultas Kedokteran Gigi Universitas Jember

Email : atik.fkg@unej.ac.id

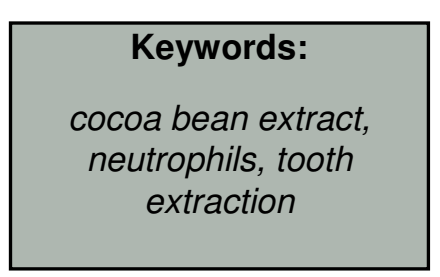

\begin{abstract}
Background: Tooth extraction is tooth removal procedure from the alveolar socket. Tooth extraction causes wounds in the form of exposed alveolar bone to the oral cavity where the treatment should be observed. Wound healing is begun by an inflammatory phase. The first defense cells that come to the wound tissue are neutrophils. The excessive post-traumatic inflammation can lead neutrophils to be overactivated. This condition may prolong and aggravate the inflammatory response. This study is to determine the effect of cocoa seed extract gel to the number of neutrophil.
\end{abstract}

Method: This research was an experimental research laboratories with the post test control group design. 24 male Wistar rats were used to be the sample. The sample were divided into 2 groups which were control and treatment group. Cocoa seed extract gel was given to the treatment group, whereas the control group didnt given the cocoa seed extract gel. The treatment and control groups were performed decaputation on the 1st, 3rd, and 7th days after tooth extraction. After decaputation was performed, socket tissue was taken to make histological preparation which was stained by Hematoxylin Eosin.

Result: The neutrophils average of the treatment group is lower than control group in the 1st, 3rd, and 7th day.

Conclusion: The result of the study showed that the $8 \%$ cocoa (Theobroma cacao L.) bean gel extract could reduce the neutrophils in rat post-extraction tooth socket.

\section{PENDAHULUAN}

Ekstraksi gigi adalah tindakan mengeluarkan gigi atau akar gigi dari dalam soket tulang. Ekstraksi gigi akan menyebabkan luka berupa terbukanya tulang alveolar pada rongga mulut. Luka akibat ekstraksi gigi perlu mendapat penanganan yang tepat seperti pemberian agen antiseptik agar tidak menimbulkan berbagai komplikasi pasca ekstraksi. Komplikasi yang sering terjadi setelah tindakan ekstraksi gigi di antaranya alveolar osteitis/dry socket yang ditandai dengan terjadinya keradangan yang berkepanjangan sehingga dapat memperlambat proses penyembuhan. ${ }^{1}$
Tubuh memiliki kemampuan secara seluler dan biokimia untuk memperbaiki integritas jaringan dan fungsinya akibat adanya luka yang biasa disebut dengan proses penyembuhan luka. Proses penyembuhan luka pasca ekstraksi gigi tidak jauh berbeda dengan penyembuhan luka lainnya pada tubuh, yang membedakan adalah bentuk anatomi dari soket pasca ekstraksi gigi. Proses penyembuhan luka pasca ekstraksi gigi melibatkan interaksi antara peristiwa seluler, molekuler, maupun vaskuler. Peristiwa tersebut terjadi dalam 3 fase penyembuhan luka, yaitu fase inflamasi, fase proliferasi, dan fase remodelling. ${ }^{1,2}$ 
Fase inflamasi merupakan respons awal dari tubuh akibat adanya luka dan biasanya berlangsung selama 1 sampai 2 hari. Fase proliferatif 2 sampai 14 hari, dan fase remodelling 14 sampai 18 hari. $^{2}$ Respon inflamasi dimodulasi sebagian oleh neutrofil. Neutrofil merupakan sel pertahanan tubuh terbanyak dalam sirkulasi yang dihasilkan oleh sumsum tulang dari stem sel hematopoetik dalam proses yang disebut dengan granulopoesis. Neutrofil kemudian dilepaskan dalam darah dan bersirkulasi sampai neutrofil menerima sinyal inflamasi. ${ }^{3}$

Neutrofil merupakan sel pertama yang merespon sinyal inflamasi yang dilepaskan dari kerusakan sel dan nekrosis sel. ${ }^{3}$ Sel yang mengalami kerusakan akibat prosedur pembedahan, trauma dan nekrosis akan melepaskan molekul DAMPs yang dapat menstimulus neutrofil bermigrasi ke sisi luka. Molekul-molekul DAMPs terdiri dari DNA, histone, high mobility group protein B1 (HMGPB1), peptida $\mathrm{N}$-formyl, Adenosine triphosphate (ATP), interleukin- $\alpha 1$ (IL- $\alpha 1$ ), dan lain-lain. DAMPs mampu mengaktivasi jaringan sekitar untuk memproduksi kemokin dan Neutrofil merupakan sel pertama yang merespon sinyal inflamasi yang dilepaskan dari kerusakan sel dan nekrosis sel. ${ }^{3}$ Sel yang mengalami kerusakan akibat prosedur pembedahan, trauma dan nekrosis akan melepaskan molekul DAMPs yang dapat menstimulus neutrofil bermigrasi ke sisi luka. Molekul-molekul DAMPs terdiri dari DNA, histone, high mobility group protein B1 (HMGPB1), peptida $\mathrm{N}$-formyl, Adenosine triphosphate (ATP), interleukin- $\alpha 1$ (IL- $\alpha 1$ ), dan lain-lain. DAMPs mampu mengaktivasi jaringan sekitar untuk memproduksi kemokin danneutrofil secara terus menerus dapat memperparah respon inflamasi serta mengakibatkan terjadinya kerusakan sel inang yang berlebihan. Hal tersebut dapat terjadi karena terjadinya pelepasan protease oleh neutrofil yang tidak terkontrol ke dalam jaringan. Proteaseprotease tersebut meliputi Cathepsin G, elastase dan proteinase-3., ${ }^{4,5}$

Salah satu tanaman yang terbukti memiliki kapasitas antiinflamasi dan antioksidan adalah kakao (Theobroma cacao L.). Kakao telah dikenal memiliki manfaat bagi kesehatan sejak abad ke-17. Kakao saat ini juga banyak diteliti dikarenakan memiliki kandungan flavonoid yang sangat tinggi. Biji kakao yang belum terfermentasi memiliki kandungan polifenol mencapai $12 \%$ hingga $18 \%{ }^{6}$ Kakao memiliki kandungan flavanol tertinggi dibandingkan jenis bahan makanan lainnya, selain itu kakao juga memiliki kandungan katekin yang sangat tinggi. ${ }^{7}$ Kandungan flavonoid yang tinggi, menyebabkan biji kakao memiliki efek bakterisidal, antioksidan, antiradikal bebas dan, antiinflamasi. Kurniawati (2019) menyatakan bahwa kandungan senyawa aktif dalam ekstrak biji kakao $8 \%$ mampu mempengaruhi jumlah sel makrofag pada luka pencabutan gigi tikus Wistar, sehingga proses inflamasi tidak berkepanjangan dan mampu mempercepat penyembuhan luka pasca pencabutan gigi. ${ }^{6}$ Oleh karena itu penulis terdorong untuk meneliti pengaruh pemberian gel ekstrak biji kakao (Theobroma cacao L.) $8 \%$ terhadap jumlah neutrofil pada soket pasca ekstraksi gigi.

\section{METODE PENELITIAN}

Penelitian ini merupakan penelitian eksperimental laboratories dengan rancangan penelitian the post test control group design. Sebelumnya dilalukan uji etik, dan dinyatakan laik etik dengan nomor 143/UN 25.8/KEPK/DL/2018, Sampel yang digunakan adalah 24 ekor tikus Wistar jantan yang kemudian dibagi menjadi 2 kelompok, yaitu kelompok kontrol yang tidak diberikan perlakuan apapun dan kelompok perlakuan yang diberi gel ekstrak biji kakao (Theobroma cacao L.) 
8\%. Konsentrasi 8\% dipilih karena pada konsentrasi tersebut, gel ekstrak biji kakao mampu mempengaruhi jumlah makrofag pada soket pasca pencabutan gigi tikus wistar jantan. ${ }^{6}$ Pembuatan gel ekstrak biji kakao 8\%, diawali dengan pembuatan ekstrak biji kakao dengan metode maserasi, menggunakan pelarut etanol 96\%. Hasil ekstrak yang diperoleh berupa sediaan pekat (konsentrasi $100 \%$ ). Dari sediaan pekat tersebut diambil 8 gram kemudian diencerkan dengan aquadest $100 \mathrm{ml}$ sehingga diperoleh konsentrasi 8\%. Proses pembuatan gel dimulai dari pencampuran CMC-Na (basis gel) dengan akuades kemudian mencampur basis gel yang telah jadi dengan ekstrak biji kakao (Theobroma cacao L.) 8\% hingga homogen. ${ }^{6}$

Semua sampel dilakukan anastesi menggunakan ketamin kemudian dilakukan ekstraksi gigi molar satu kiri bawah. Pada kelompok kontrol, diberikan gel ekstrak biji kakao (Theobroma cacao L.) $8 \%$ setiap harinya sampai sehari sebelum dilakukan dekaputasi.

Sampel dilakukan dekaputasi pasca tindakan ekstraksi gigi pada hari ke-1, ke-3, dan hari ke-7. Pembuatan preparat histologis dilakukan dengan arah pemotongan bukal ke lingual sehingga akan terlihat gambaran soket gigi. Preparat yang telah dibuat dilakukan pewarnaan dengan pengecatan Hematoxylin Eosin.

Preparat yang telah jadi, diamati menggunakan mikroskop binokuler pembesaran 400x. Sel neutrofil diamati dan dihitung pada 3 lapang pandang.

\section{HASIL PENELITIAN}

Hasil penelitian diamati pada mikroskop dan terlihat gambaran soket serta sel neutrofil yang menempel pada jaringan ikat pada setiap kelompoknya.

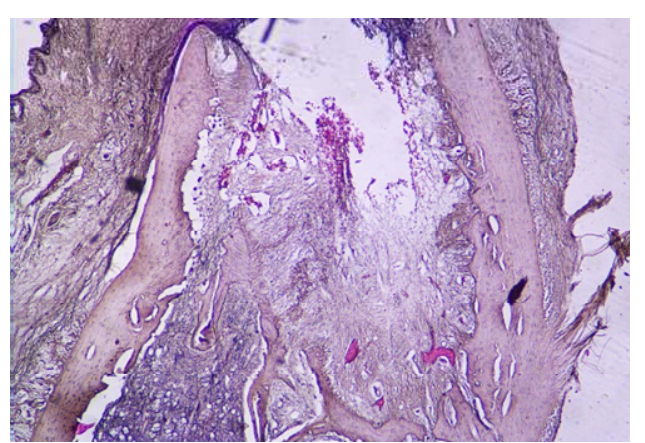

Gambar 1. Gambaran soket gigi tikus pasca tindakan ekstraksi gigi. Pengamatan dengan pembesaran 40x

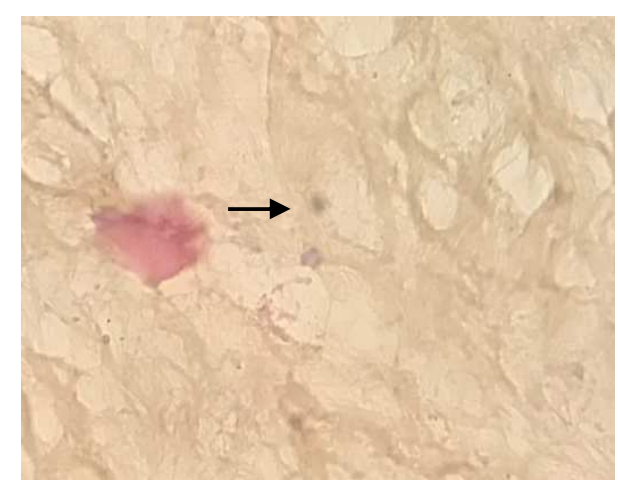

Gambar 2 . Gambaran neutrofil (anak panah) pada jaringan soket gigi tikus pasca ekstraksi dengan pembesaran 1000x 

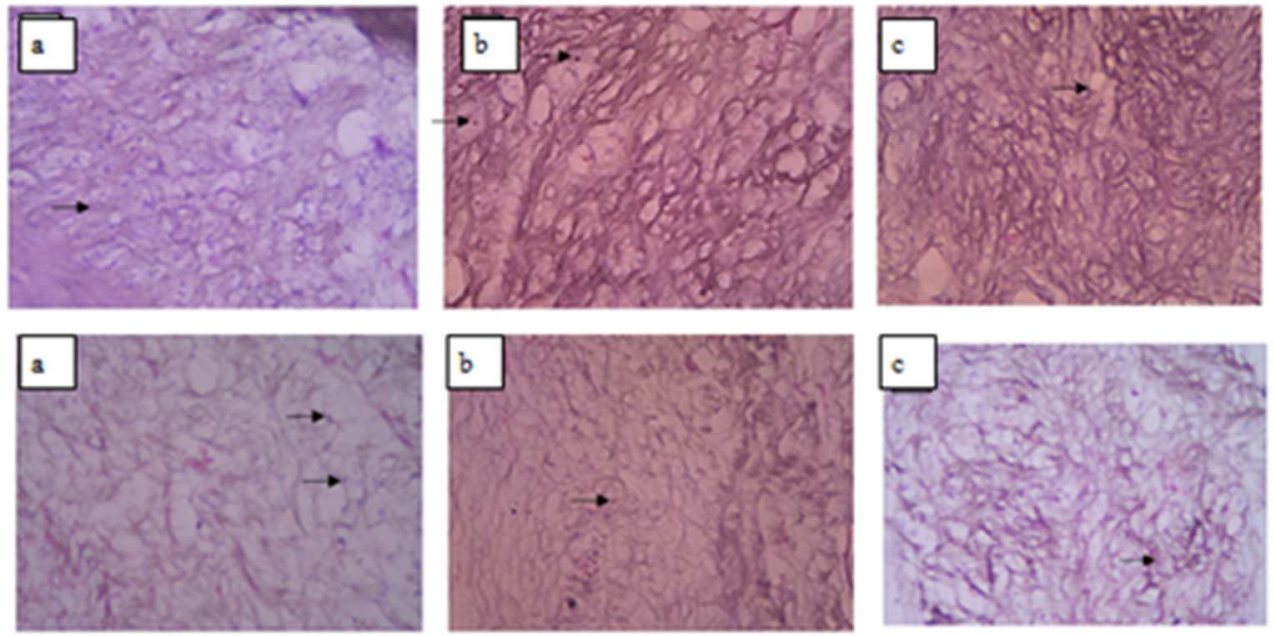

Gambar 3. Gambaran histologis sel neutrofil pada soket tikus wistar jantan (anak panah) yang diamati menggunakan mikroskop binokuler pada pembesaran 400x dengan pewarnaan Haematoxilin-eosin. Gambar atas (a) Kelompok perlakuan hari ke-1, (b) Kelompok perlakuan hari ke-3, (c) Kelompok perlakuan hari ke-7, Gambar bawah (a) Kelompok kontrol hari ke-1, (b) Kelompok kontrol hari ke-3, dan (c) Kelompok kontrol hari ke-7.

\section{DISKUSI}

Berdasarkan pengamatan dan perhitungan menggunakan mikroskop binokuler dengan pembesaran 400x terhadap sel neutrofil, didapatkan jumlah rerata sel neutrofil pada masingmasing kelompok (Tabel 1).

Tabel 1. Rerata dan standar deviasi (SD) jumlah sel neutrofil pada soket gigi tikus pasca ekstraksi.

\begin{tabular}{ccccccc}
\multirow{2}{*}{$\begin{array}{c}\text { Kelom } \\
\text { Pok }\end{array}$} & \multicolumn{2}{c}{ Hari Ke-1 } & \multicolumn{2}{c}{ Hari Ke-3 } & \multicolumn{2}{c}{ Hari Ke-7 } \\
\cline { 2 - 7 } & $\begin{array}{c}\text { Re- } \\
\text { rata }\end{array}$ & SD & $\begin{array}{c}\text { Re- } \\
\text { rata }\end{array}$ & SD & $\begin{array}{c}\text { Rer } \\
\text {-ata }\end{array}$ & SD \\
\hline \multirow{2}{*}{ Kontrol } & 1,8 & 1,0 & 1,0 & 0,7 & 0,1 & 0,3 \\
& 1 & 9 & 0 & 2 & 9 & 3 \\
\hline Perlaku & 0,9 & 0,6 & 0,5 & 0,4 & 0,0 & 0,0 \\
-an & 2 & 8 & 8 & 7 & 1 & 0 \\
\hline
\end{tabular}

Hasil perhitungan menunjukkan bahwa terjadi penurunan jumlah neutrofil seiring dengan bertambahnya hari. Jumlah neutrofil pada kelompok perlakuan dengan ekstrak biji kakao $8 \%$ lebih rendah dibandingkan dengan jumlah neutrofil pada kelompok kontrol. Jumlah sel neutrofil tertinggi berada pada kelompok kontrol pada hari ke-1 dengan jumlah rerata 1,81. Selisih penurunan neutrofil antara kelompok kelompok kontrol dan kelompok perlakuan pada hari ke-1 adalah 0,89, hari ke-3 sebesar 0,42 dan hari ke-7 sebesar 0,18.

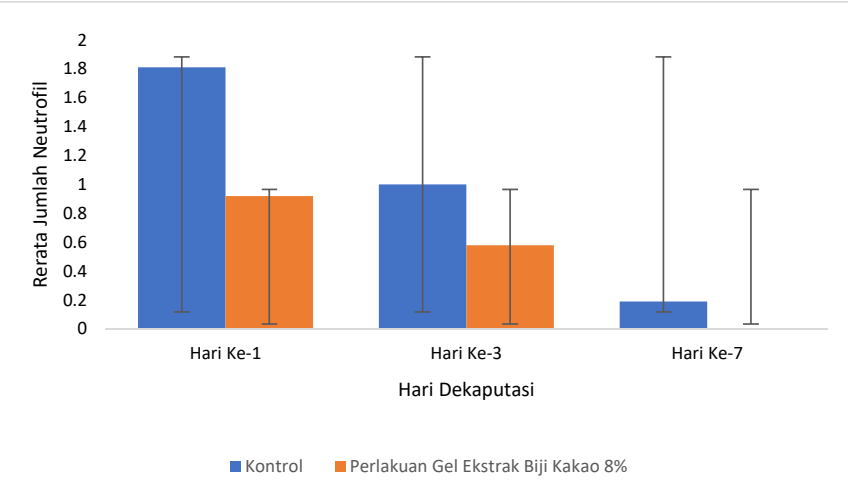

Grafik 1. Rerata jumlah neutrofil pada soket gigi tikus pasca pencabutan pada kelompok kontrol dan kelompok perlakuan.

\section{PEMBAHASAN}

Penelitian ini memilih ekstrak biji kakao dibuat dalam sediaan gel. Sediaan gel dipilih karena memudahkan dalam pengaplikasian bahan 
ekstrak biji kakao. Pengaplikasian gel secara topikal juga mampu mempertahankan dosis obat pada jaringan yang dituju secara langsung sehingga obat mampu memberikan efek terapi yang optimal. Pemberian obat secara topikal tidak melewati sistem pencernaan dan hati sehingga meningkatkan bioviabilitas kandungan ekstrak. Kandungan ekstrak juga dilindungi dari degradasi akibat derajat keasaman dan enzim dalam saluran pencernaan. ${ }^{8}$ Bentuk sediaan gel memiliki kelemahan berupa sifat tidak mudah melekat sehingga menjadikannya mudah larut akibat adanya saliva rongga mulut sehingga tidak dapat bertahan lama di dalam soket. ${ }^{9}$

Berdasarkan hasil pengamatan didapatkan penurunan jumlah neutrofil yang signifikan pada kelompok tikus yang diberikan gel ekstrak biji kakao (Theobroma cacao L.) 8\% dibandingkan dengan kelompok kontrol. Selisih penurunan terbesar antara kelompok kontrol dan kelompok perlakuan terjadi pada hari ke-1. Hal ini disebabkan karena neutrofil merupakan sel pertahanan pertama yang akan menginfiltrasi jaringan pada sisi luka. Neutrofil akan menjadi sel yang dominan dalam waktu 24 jam setelah terjadinya luka. ${ }^{10}$

Proses perekrutan neutrofil dapat terjadi karena adanya modulasi dari beberapa jenis sitokin, mediator lipid dan lain lain yang dapat memicu terjadinya migrasi neutrofil. Kerusakan sel yang diakibatkan oleh tindakan ekstraksi gigi dapat melepaskan molekul DAMPs yang dapat menstimulus neutrofil bermigrasi ke sisi luka. Molekul-molekul DAMPs terdiri dari DNA, histone, high mobility group protein B1 (HMGPB1), peptida $\mathrm{N}$-formyl, Adenosine triphosphate (ATP), interleukin- $\alpha 1$ (IL- $\alpha 1$ ), dan lain-lain. DAMPs mampu mengaktivasi jaringan sekitar untuk memproduksi kemokin dan mediator lipid yang merupakan mediator kuat kemotaksis neutrofil seperti C-X-C chemokine ligand 8 (CXCL 8) dan leukotrine $\mathrm{B}_{4}\left(\mathrm{LTB}_{4}\right)$. Pelepasan mediator-mediator tersebut menyebabkan jumlah neutrofil semakin meningkat pada sisi luka. ${ }^{3}$

Jumlah neutrofil menurun seiring berjalannya waktu dan sangat menurun (rerata 0,01) pada kelompok perlakuan hari ke-7. Sangat sedikit ditemukannya neutrofil pada hari ke-7 disebabkan karena fase inflamasi berakhir pada hari ke-7 dan akan digantikan dengan fase proliferasi sehingga sel-sel neutrofil jumlahnya menurun pada sisi luka. Hal tersebut menandakan bahwa pengaruh gel ektrak biji kakao (Thebroma cacao L.) terhadap jumlah neutrofil masih tergolong normal. Sel neutrofil akan berada di jaringan sampai hari ke-3 pasca terjadinya luka namun tidak menutup kemungkinan fase inflamasi akan berlanjut apabila terdapat trauma yang berlebihan seperti pada kelompok kontrol, dimana ditemukannya sel neutrofil pada jaringan dihari ke-7, artinya bahwa pada kelompok kontrol diduga terjadi inflamasi yang berkepanjangan dan dapat mengakibatkan penyembuhan luka terhambat. ${ }^{9}$

Penurunan jumlah neutrofil pada kelompok perlakuan menandakan bahwa pemberian gel ekstrak biji kakao (Theobroma cacao L.) 8\% secara intraalveolar dapat menurunkan jumlah neutrofil secara signifikan. Hal ini terjadi karena pada kakao terdapat kandungan-kandungan yang dapat menurunkan jumlah sel inflamasi, termasuk neutrofil. Berdasarkan penelitian Kurniawati (2019) menyebutkan bahwa ekstrak biji kakao (Theobroma cacao L.) $8 \%$ memiliki kadar antioksidan yang tinggi yakni sebesar $43,6 \%$, polifenol $11,84 \%$ dan flavonoid sebesar $10,9 \%{ }^{6}$

Penjelasan penurunan jumlah neutrophil pada kelompok perlakuan dibanding kelompok kontrol pada penelitian ini diduga karena adanya kandungan senyawa polifenol dan flavonoid serta antioksidan dimana hal ini juga dinyatakan oleh beberapa peneliti lain.6,11,12 Senyawa aktif yang 
banyak terkandung dalam biji kakao adalah polifenol. Kandungan polifenol terbesar dalam biji kakao adalah flavonoid. ${ }^{11,12}$ Kakao mengandung flavanol (subfamili dari flavonoid) tertinggi dari semua bahan makanan berdasarkan berat, dan menjadi penyumbang asupan diet flavonoid yang signifikan. ${ }^{12}$ Flavonoid pada kakao memiliki efek antioksidan dan antiinflamasi sehingga mampu menekan proses inflamasi yang terjadi. ${ }^{10}$ pada penelitian ini inflamasi akibat pencabutan gigi. Kakao juga merupakan sumber antioksidan tertinggi. Dilaporkan sebuah penelitian yang menguji konsentrasi total senyawa redoks pada 1113 makanan yang berbeda, dari 50 makanan dengan kemampuan antioksidan tertinggi, 5 diantaranya adalah kakao. ${ }^{12}$

Mekanisme penurunan neutrophil terkait dengan kandungan senyawa aktif dalam kakao dapat melalui berbagai cara. Andujar dkk (2012) melaporkan bahwa polifenol khususnya flavonoid pada biji kakao diduga memegang peranan penting dalam menurunkan jumlah neutrofil. Flavonoid kakao terbukti memiliki kemampuan menghambat metabolisme asam arakidonat, aktivitas enzim lipooksigenase, dan sintesis beberapa mediator inflamasi. ${ }^{13}$ Penghambatan metabolisme asam arakidonat akan berujung pada penurunan jumlah pembentukan tromboksan A2 yang merupakan kemoatraktan kuat pada perekrutan neutrofil di area luka. ${ }^{13}$

Mekanisme lain penurunan neutrophil diduga terkait dengan peran enzim lipooksigenase. Aktivitas enzim lipooksigenase mampu memicu terbentuknya leukotrin melalui pemecahan lowdensity lipoprotein (LDL). Pemecahan LDL dilakukan melalui 2 langkah yang terdiri dari proses secara langsung dan proses peroksidase lipid. Flavonoid mampu menekan kedua langkah sintesis leukotrin tersebut. Flavonoid kakao memiliki kemampuan antileukotrin dengan menghambat enzim 5-LOX. Penghambatan aktivitas enzim lipooksigenase oleh flavonoid kakao akan menurunkan jumlah leukotrin dalam jaringan. Leukotrin merupakan salah satu kemoatraktan kuat dalam proses rekrutmen neutrofil untuk bermigrasi pada jaringan di area luka. ${ }^{3}$

Pembentukan sitokin proinflamasi merupakan salah satu aspek terpenting dalam proses terjadinya inflamasi. Flavonoid kakao memiliki kemampuan menghambat proses inflamasi dengan menghambat kerja enzim siklooksigenase 2 yang mampu menyintesis meditor-mediator proinflamasi dari asam arakhidonat. Selain menghambat enzim siklooksigenase, flavonoid kakao juga mampu menghambat enzim lipooksigenase- 5 manusia. Hal tersebut mengindikasikan terdapat kapasitas antileukotrin pada kakao yang memberikan kemampuan antiinflamasi, vasoprotektif dan antibronkokonstriksi. ${ }^{13}$

Penurunan jumlah neutrofil pada kelompok perlakuan juga disebabkan oleh kapasitas antioksidan pada biji kakao. Kandungan antioksidan dalam gel ekstra kakao $8 \%$ pada penelitian ini sebesar $43.6 \%$. Kakao memiliki kapasitas antioksidan dan kandungan flavonoid yang lebih tinggi dua kali lipat dibandingkan teh hijau dan anggur merah, serta 4 kali lipat dibandingkan teh hitam. Ekstrak kakao mampu mengeliminasi radikal bebas seperti 2,2-diphenyl-1pycrylhydrazyl (DPPH), azino-bis (3ethylbenzthiazoline-6-sulphonic acid) (ABTS+), superoksida, hipoklorida dan peroksinitrat. ${ }^{13}$

Kakao mengandung banyak flavonoid epikatekin, katekin, prosianidin B2, dan prosianidin B1. ${ }^{11,14}$ Kakao juga terdapat kandungan polifenol seperti kuersetin, isokuersitrin, naringenin, luteolin dan dan apigenin walaupun dalam jumlah yang sedikit. ${ }^{11}$

Dilaporkan bahwa senyawa katekin yang memiliki kemampuan antiinflamasi dan antioksidan 
banyak terkandung dalam kakao, daun teh hijau, anggur merah, cokelat dan bir. Katekin terbukti mampu menurunkan mediator interleukin 5, interleukin 13, dan mampu memperbaiki keseimbangan fungsi sel $\mathrm{T}$ helper tipe 1, dan sel T helper tipe 2 sehingga memiliki kapasitas antialergi dan antiinflamasi. ${ }^{14}$ Selain itu, katekin yang terkandung dalam kakao memiliki kemampuan untuk menurunkan stres oksidatif sehingga dapat mencegah kerusakan syaraf, meningkatkan kerja enzim antioksidan dan mengikat ROS. Penurunan ROS pada sel syaraf dapat menghentikan aktivasi mediator inflamasi seperti TNFa, COX-2, NF-k $\beta$. Apabila pembentukan ROS ditekan, maka mediator proapoptotic seperti Bcl-2 dan caspase 9 juga dapat diturunkan atau dihambat pembentukannya. ${ }^{15}$

Inflamasi merupakan tahap pertama dan tahap penting dalam respons penyembuhan luka. Neutrofil merupakan sel inflamasi pertama yang direkrut ke lokasi luka dari sirkulasi.6,10 Melalui berbagai reseptor pada permukaan sel neutrofil, sel neutrofil mampu merespon sinyal inflamasi yang terjadi. Reseptor-reseptor pada permukaan sel neutrofil tersebut antara lain reseptor $G$ protein coupled chemokine dan kemoatraktan, reseptor Fc dan reseptor-reseptor adesi seperti selectin ligands dan integrin, berbagai reseptor sitokin, dan reseptor C-type lectins dan Toll-like receptors. ${ }^{6}$

Peranan neutrofil lainnya adalah mencegah infeksi dengan melawan berbagai mikroorganisme patogen baik berupa bakteri maupun jamur yang menginvasi ke dalam tubuh. ${ }^{3}$ Terdapat tiga fungsi antimikroba utama yang dimiliki oleh neutrofil, yakni fagositosis, degranulasi, dan pelepasan materi nuklear dalam bentuk Neutrophil Extracellular Traps (NETs). ${ }^{10}$ Neutrofil memiliki kemampuan antimikroba dan antijamur, berbagai zat kimia seperti antimicrobal peptides, reactive oxygen species, dan protease seperti elastase, cathepsin
G, dan protease-3 untuk melawan mikroba. 3,10 Pelepasan mediator-mediator tersebut juga dapat menyebabkan kerusakan jaringan yang berlebih. Aktivitas neutrofil untuk mensterilisasi sisi luka tidak spesifik terhadap organisme ekstrinsik, sehingga selain membunuh mikroba, neutrofil juga menargetkan sel tubuh. Neutrofil akan membunuh mikroba secara fagositosis. Meskipun penghancuran agen infeksi terjadi secara intraseluler, pelepasan molekul sitotoksik ke lingkungan ekstraseluler juga dapat merusak jaringan tubuh lainnya. Molekul ROS, elastase, cathepsin G, dan protease-3 dapat memicu kerusakan jaringan dan kondisi inflamasi yang persisten. ${ }^{3,16}$

Peran neutrofil dalam penyembuhan luka melalui berbagai cara, antara lain kemampuannya dalam mengeliminasi neutrophil yang berisi debris dan mengawalnya sehingga neutrophil hilang dari daerah luka. Seperti makrofag, neutrofil juga dapat memfagosit atau menginduksi apoptosis sehingga proses inflamasi menjadi lebih cepat dan selanjutnya memasuki fase penyembuhan. Hal ini merupakan titik peralihan peran netrofil yang semula dari pro-inflamasi menjadi pendukung perbaikan jaringan. ${ }^{17}$ Peran selanjutnya pada saat luka dilakukan makrofag, makrofag proinflamsi,akan teraktivasi, sehingga mengeluarkan berbagai macam mediator dan sitokin seperti IL-1, IL-6, IL-12, TNFa, inducible nitric oxide synthase (iNOS). Selain itu makrofag juga memproduksi chemoatractan sehingga leukosit tambahan akan berdatangan menuju tempat luka,yang akhirnya luka menjadi lebih cepat sembuh. ${ }^{12,18}$. Senyawa caffeine methylxanthine merupakan bagian dari alkaloid. Alkaloid merupakan komponen utama pada berbagai makanan seperti kopi, coklat dan teh. Alkaloid berperan sebagai sumber antioksidan potensial. Saat terjadi luka pada jaringan, sel-sel yang rusak akan mengeluarkan Reactive Oxygen 
Species (ROS), saat itu diperlukan antioksidan yang banyak untuk menghalau radikal bebas (ROS) sehingga luka akan cepat menutup. Sebenarnya anti-oksidan secara normal sudah diproduksi oleh tubuh, akan tetapi pada proses kerusakan jaringan, diperlukan jumlah anti-oksidan yang lebih sehingga proses penyembuhan menjadi lebih cepat. ${ }^{16,18,19}$

\section{SIMPULAN DAN SARAN}

Berdasarkan hasil penelitian ini dapat disimpulkan bahwa gel ekstrak biji kakao (Theobroma cacao L.) berpengaruh terhadap jumlah neutrofil pada soket gigi tikus pasca ekstraksi.

Saran penelitian ini adalah perlu dilakukan penelitian lebih lanjut mengenai pengaruh gel ekstrak biji kakao (Theobroma cacao L.) dengan metode pengaplikasian topikal yang diikuti dengan penjahitan pada soket untuk menjaga obat tetap berada pada soket selain itu juga perlu dilakukan penelitian lebih lanjut mengenai waktu pengamatan sel neutrofil dengan durasi waktu per-menit sesaat setelah terjadinya luka agar dapat lebih terlihat perubahan jumlah sel neutrofil.

\section{DAFTAR PUSTAKA}

1. Saghiri MA, Asatourian A, Sheibani N. Angiogenesis and The Prevention of Alveolar Osteitis: a Review Study. J korean Assoc Oral Maxillofac Surg 2018; 44: 93

2. Gonzales ACO, Andrade DA, Costa TF, Medrado AR. Wound Healing: A Literature Review. An Bras Dermatol 2016; 91(5): 614-20

3. Wang, jing. Neuthrophils in tissue injury and repair. Cell and tissue Research 2018; 371: 532.

4. Hazeldine JP. Hampson, Lord JM. The impact of trauma on neutrophil function. Injury 2014; 45(12): 1824-1833.

5. Kruger $P$, Saffarzedah $M$, Harti $D$, et al. Neutrophils: Between Host Defence, Immune Modulation, and Tissue Injury. Plos Pathog 2015; 11(3): e1004651
6. Kurniawati, A. Zainul C, Melati HP. Efektivitas Ekstrak Biji Kakao (Theobroma Cacao L.) terhadap Penyembuhan Luka Pencabutan Gigi pada Sel Makrofag. Denta Jurnal Kedokteran Gigi 2019; 13 (2): 49-57

7. Andujar I, Recio MC, Ginner RM, et al. Cocoa phenols and their potential benefits for human health. Oxidative medicine and cellular longevity 2012; 2012: 1-23.

8. Futosi, K, Fodor, S, Mocsai, A. Neutrophil sell surface receptors and their intracellular signal transduction pathways. International immunopharmacology 2013; 17: 638.

9. Rosales, Carlos. Neutrophil : A cell with many roles in inflammation or several cell types?. Front. Physiol 2018; 9: 113.

10. Zulfitri, A. M. I., C. Khoswanto, Istiati. 2012. Efek Gel Ekstrak Daun Binahong terhadap Jumah Sel Fibroblas dan Pembuluh Darah Kapiler pada Luka Pasca Ekstraksi Gigi Marmot. Oral Biology Dental Journal; 4(2): 4-5.

11. Mantovani A, Cassatella MA, Costantini C, et al. Neutrophils in the activation and regulation of innate and adaptive immunity. Nat Rev Immunol 2011; 31 (11): 519.

12. Goya L, Martin MA, Sarria B, et al. Effect of cocoa and its flavonoids on biomarkers on inflammation: studies of cell culture, animals and human. Nutrients 2016; 8: 212.

13. Andujar, I, Recio MC, Ginner RM, et al. Cocoa polyphenols and their potential benefits for human health. Oxidative medicine and cellular longevity 2012; 2012: 1: 23

14. Cosarca S, Tanase C, Muntean DL. Therapeutics aspects of Catechins and its derivatives-An Update. ABMJ 2019; 2(1): 2129.

15. Survayansi SV, Kulkarni YA. NFK- $\beta$ : A potential target in the management of vascular complications of diabetes. Front. Pharmacol 2017; 8: 1-12.

16. Wilgus, Traci A, Roy, et al. Neutrophils and Wound Repair: Positive and Negative Reactions. Advances in Wound Care 2013; 2 (7).

17. Koh TJ, Di Pierro LA. Inflammation and Wound Healing, The Role of the macrophage. Expert Rev. Mol Med 2011;13: e23.

18. Brancato SK, Albina JE. Wound macrophages as a key regulators of repair; origin, phenotype and function. Am J Pathol 2011; 178(1): 19-25.

19. Bonyanian ZMR, Roselin B. Caffein and its potential role in attenuating impaired wound healing. Journal of Caffeine Research 2016; 5(4): 141-8. 